\title{
Petro-Structural Characterization of Bonguen Area, Nyong Series, Cameroon: Insight into the Northern Extension of Kribi-Campo Shear Zone
}

\author{
Kouankap Nono Gus Djibril ${ }^{1, ~ *, ~ N j i o s s e u ~ T a n k o ~ E v i n e ~ L a u r e ~}{ }^{2}$, Takodjou Wambo Jonas Didero ${ }^{3}$, \\ Kamguia Woguia Brice ${ }^{3}$, Afahnwie Ngambu Aloysius ${ }^{4}$, Fomena Tchinda Hermann ${ }^{1}$, \\ Folah Mewa Cathy Laurianne ${ }^{1}$
}

\author{
${ }^{1}$ Department of Geology, HTTC, University of Bamenda, Bambili, Bamenda, Cameroon \\ ${ }^{2}$ Department of Earth Sciences, Faculty of Science, University of Dschang, Dschang, Cameroon \\ ${ }^{3}$ Department of Earth Sciences, Faculty of Science, University of Yaoundé I, Yaoundé, Cameroon \\ ${ }^{4}$ Department of Geology, University of Buea, Buea, Cameroon
}

Email address:

kouankap@yahoo.fr (K. N. G. Djibril)

${ }^{*}$ Corresponding author

\section{To cite this article:}

Kouankap Nono Gus Djibril, Njiosseu Tanko Evine Laure, Takodjou Wambo Jonas Didero, Kamguia Woguia Brice, Afahnwie Ngambu Aloysius, Fomena Tchinda Hermann, Folah Mewa Cathy Laurianne. Petro-Structural Characterization of Bonguen Area, Nyong Series, Cameroon: Insight into the Northern Extension of Kribi-Campo Shear Zone, West Ethiopia. Earth Sciences. Vol. 7, No. 5, 2018 , pp. $236-241$. doi: 10.11648/j.earth.20180705.15

Received: September 22, 2018; Accepted: October 10, 2018; Published: October 24, 2018

\begin{abstract}
The west Bonguen area is located within latitudes $03^{\circ} 25^{\prime} \mathrm{N}$ to $\mathrm{N} 03^{\circ} 39^{\prime} \mathrm{N}$ and longitudes $10^{\circ} 04^{\prime} \mathrm{E}$ to $10^{\circ} 09^{\prime} \mathrm{E}$ in South Cameroon. It belongs to the Nyong Series which is the north-western extension of the Congo Craton in Cameroon. In order to highlight the extension of the Kribi-Campo shear zone, petrographic studies and structural analysis were carried out. Mylonitic metagranodiorite outcropping as a large dome in biotite gneiss basement rocks, it is the main rock type in the study area, it is made up of Kfs $+\mathrm{Qtz}+\mathrm{Bt}+\mathrm{Pl}+\mathrm{Op}$. Majority of the minerals shows deformation marks such as sigmoidal shape of Kfs, rolling extension of Qtz ribbons, Subgrains of Qtz and kink-band of Bt. Three (03) deformation phases (D1, D2, and D3) were denoted in Bonguen west. The D1 deformation developed S1 foliation in biotite gneiss basement rocks and is characterized by the alternation of parallel compositional bands and lithological units. The D2 deformation developed S2 mylonitic shistosity, Shear bands (C2-planes) develop oblique to the main S2 mylonitic schistosity (S2-plane) showing dextral ductile shear, V2 veins and B2 boudins. The D3 phase is exclusively highlighted by brittle features such as V3 veins, F3 joints and faults. The area consequently underwent a polyphases ductilo-fragile tectonism dominated by a dextral thrusting kinematics. Bonguen area is here considered as a segment of the northern extension of the Kribi-Campo fault.
\end{abstract}

Keywords: Bonguen, Kribi-Campo Fault, Ductilo-Fragile Tectonics, Mylonites

\section{Introduction}

The crustal structural evolution of the African continent was dominated by several tectono-metamorphic events [1]: the Archean orogeny (3.0-2.5Ga), the Eburnean or Birrimian orogeny $(2.2-1,8 \mathrm{Ga})$, the Kibarian $(\sim 1,3 \mathrm{Ga})$ and the Panafrican orogeny ( $600-500 \mathrm{Ma})$. In Cameroon the Birimian ages have so far been reported mostly in the Nyong series [2]. The Nyong series is the northwestern part of
Congo craton in Cameroon, it is a metasedimentary and metavolcanic rocks unit hosting the Kribi-Campo Shear Zone (KCSZ) as the main structural characteristic [3, 4, 5, 6]. The $\mathrm{KCSZ}$ is a precambrian mega dextral shear zone [7,8], well studied from Kribi towards the south (Campo), but its northern extension still controversial. Therefore this paper present the petro-structural characteristics of Bonguen area located in the northern extension of KCSZ with the aims of provide insights on its extension. 


\section{Geological Setting}

The geology of the Southern part of Cameroon is represented by the Ntem complex, which is the NorthWestern portion of the Congo craton (Figure 1). It is subdivided in 03 series: the Ayna Series at the East, the Ntem Series at the Center, and the Nyong series at the west $[9,10]$. The Nyong series consists of metasedimentary and metavolcanic rocks, as well as syn to late-tectonic granitoids and syenites. Biotite-hornblende gneisses, locally appear as grey gneisses of TTG composition. Also found in the area are orthopyroxene-garnet gneisses (charnockites), garnetamphibole-pyroxenites, and banded iron-formation $[4,2,11$, 12]. SHRIMP U/Pb geochronological analysis on detrital zircons from Nyong series [2] yield Mesoarchaen to Paleoproterozoic ages giving the maximum deposition age of the series affected by a granulite facies metamorphism associated with ubiquitous flat-lying foliation and syntectonic plutonism (2050 Ma). The same aforementioned study revealed that a metagranodiorite collected from Bonguen did not display Archean zircon inheritance. It rather led to the conclusion that the emplacement ages of the Bonguen metagranodiorite is dated at $2066 \pm 4 \mathrm{Ma}$.

Furthermore, at some few kilometers to the south of Bonguen, [7] mapped out protomylonitic to mylonitic granitoids and gneisses. The author in Fifinda-Londji area, located between south of Bonguen and North of Kribi, has observed 3 deformation phases (D1, D2 and D3) with dextral kinematics dominance. [8] updated and upgraded the knowledge on KCSZ, the authors highlighted 03 deformation phases, D1 characterized by foliation and metamorphic banding, D2 by isoclinal folds and regional foliation while D3 is characterized by an upright fold, subvertical strike slip shear zone and mylonitic foliation.

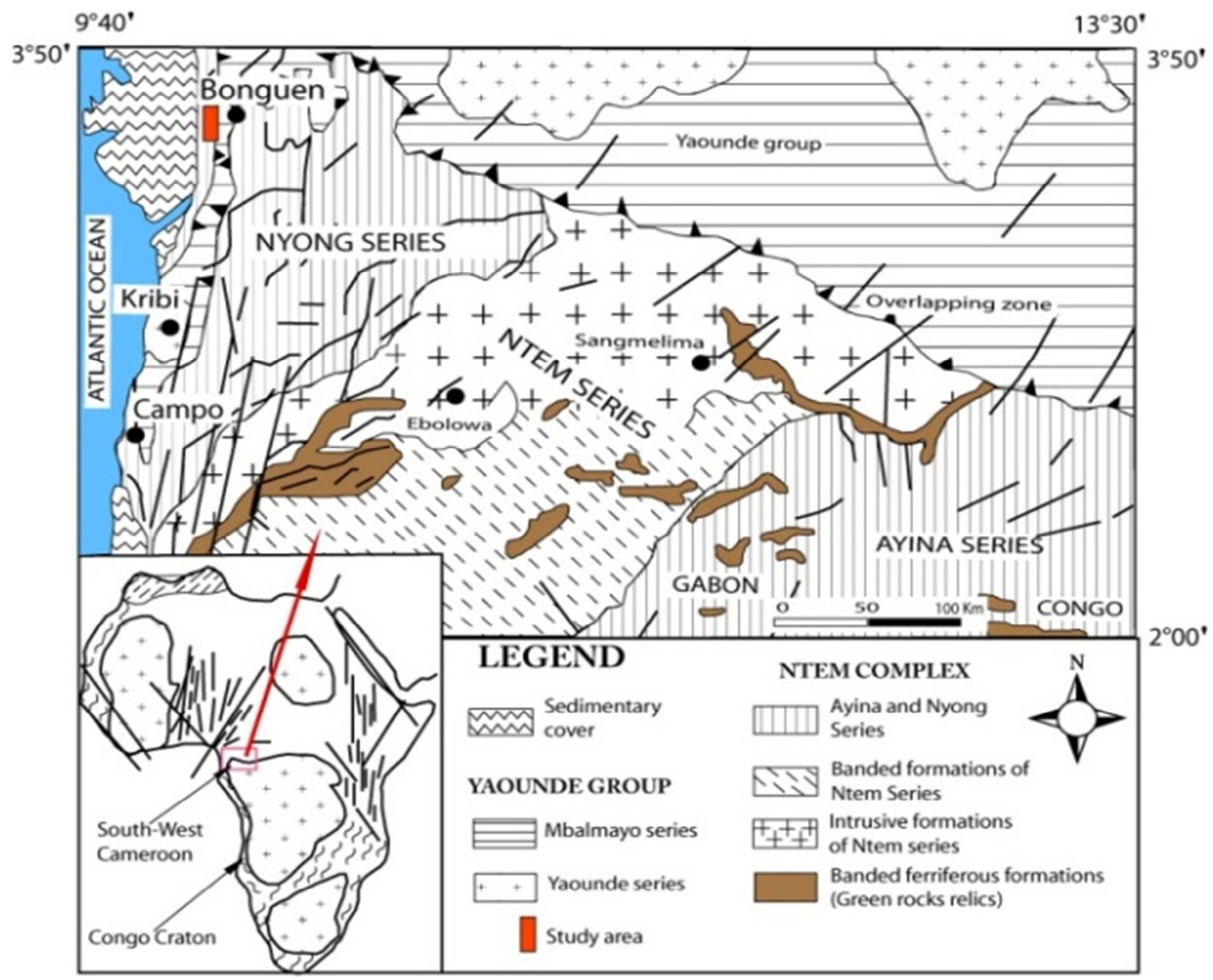

Figure 1. Geological map of southwestern Cameroon (adapted from [13, 14]).

\section{Material and Methods}

\subsection{Field Survey}

The exploration method used in this work is a field survey based on the search of outcrops with a sample grid. Due the thick soil cover which considerably hinders the observation of basement rocks on which the study is based, the search of outcrops in such an environment is very tedious. In order to make this field campaign a successful one, we used the following steps: (i) We moved round the study area searching for rock outcrops on which important information was collected; (ii) Once identified, photographs of the outcrops were taken from different angles in oder to have an idea of the dimensions and orientation of the outcrops; (iii) Structural measurements are then collected. These 
measurements took into consideration the orientations of the structural elements, their extension and the characterization of these elements; (vi) Finally the samples were characterized insitu before being carefully extracted and labelled for petrographic studies.

\subsection{Tools and Used Data}

Data used in this work are field structural measurements and thin sections microanalysis. We used binocular microscope to study thin section and identify different microstructures. Then as far as Stereographic projection is concerned Stereonet software were used to characterize field structural measurements.

\section{Results}

\subsection{Petrography}

The petrographic investigations in West-Bonguen area reveal metagranodiorite as the main rock type showing features of mylonitization. The rocks outcropas large domes hundreds of meters (figure 2A) striking almost N-S in biotite gneiss basement rocks. From the field and hand specimen, the color of the rock is grayish white, and some minerals are visible without handlens. Mylonitic features are clearly underlined by large ( $\mathrm{mm}$ to $\mathrm{cm}$ ) crystals of feldspar exhibiting sigmoidal shape, millimetric quartz ribbons associated with preferred orientation biotite crystals.

Under the microscope the rock exhibits a heterogranular blastic texture made up of:

K-feldspars (35\%) which are sub-euhedral with a sigmoid form (figure 2E). Some crystals develop cracks and are surrounded with sub-grains of quartz and/or lamellae of biotite. The K-feldspar sizes ranging from 0.2 to $3 \mathrm{~mm}$, and are frequently associated with quartz, biotite and plagioclase.

Quartz (30\%) which occurs in two habitus (figure $2 \mathrm{~F}$ ): the micro grains and the porphyroblasts. Micro grains $(<0.1 \mathrm{~mm})$ are found surrounding large crystals where they display a feature called border granulation (figure 2C). Quartz micro grains are also found as inclusions in large crystal of other minerals. The habitus of porphyroblasts $(0.5-0.7 \mathrm{~mm})$ is represented by large sub-hedral to anhedral quartz crystals. Some crystals form elongated ribbons. They display rolling extinction and are associated with K-feldspars.

Biotite $(20 \%)$ represents most essential of ferromagnesian minerals. It occurs as stacked and crushed micro crystal lamellaes. They are all elongated and are organized in bands that alternate roughly with light mineral bands. Some crystals are found as inclusions within K-feldspars and plagioclase. It equally fills cracks located within K-feldspars.

Plagioclases $(10 \%)$ occur as subhedral and sub-rounded crystals. They display polysynthetic twinning. Their sizes vary from $0.2 \mathrm{~mm}$ to $1 \mathrm{~mm}$. They are associated with quartz, $\mathrm{K}$-feldspar and biotite (figure 2D).

Opaque minerals $(5 \%)$ constitute the accessory phase of the rock. They are found as inclusions within large crystal of other minerals and as a result of the destabilization of biotite.
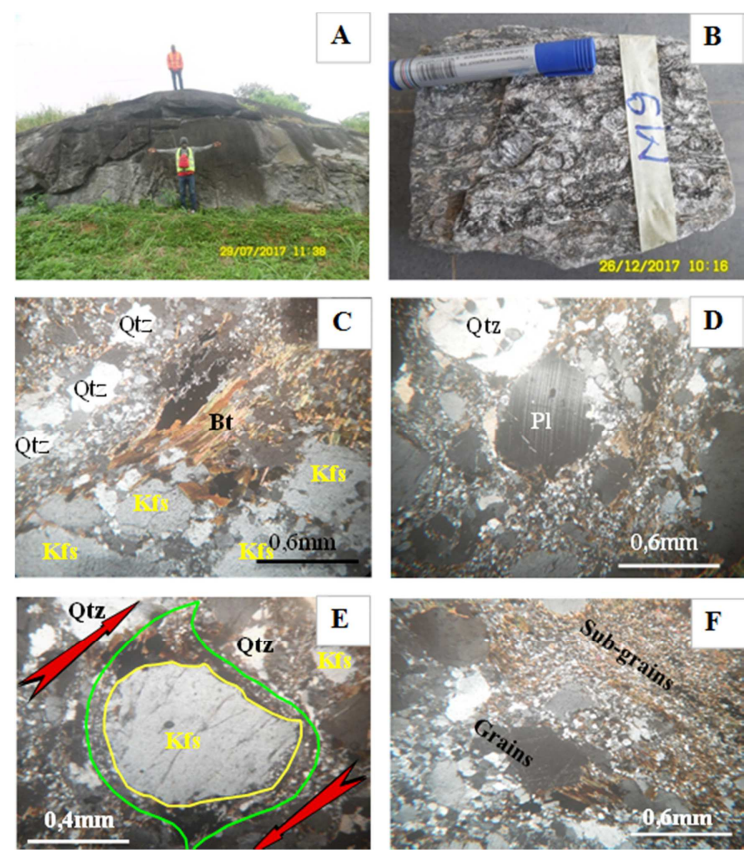

Figure 2. field photos of metagranodiorite A) Outcrops, B) hand specimen sample. Photomicrographs under polarized light of the mylonitic metagranodiorite: (C) Overall mineral composition of the studied rock; (E) $K$-feldspars dextral sigmoid with border granulation; $(D, F)$ Coarse grains and fine grains habitus.

\subsection{Structural Analysis}

Three (03) deformation phases were mapped and identified in West Bonguen area: D1, D2 and D3.

\section{D1 deformation phase}

The D1 deformation phase is characterized by: S1 foliation in biotite gneiss basement rocks showing alternation of parallel compositional bands and lithological units (figure $3 a$ and $3 b$ ). The thicknesses of the bands vary from few millimeters to about 2 centimeters. The light bands contain minerals such as quartz and feldspars while the dark band mainly contains biotite flakes and ferromagnesian minerals. The average foliation attitude is $\mathrm{N} 070^{\circ} \mathrm{E} 61 \mathrm{SSE}$ (figure $3 \mathrm{a}$ and $3 \mathrm{~b}$ ).

\section{D2 deformation phase}

This phase is identified by the S2 mylonitic schistosity, the C2 shear, V2 veins and B2 boudins. Shear bands (C2-planes) develop oblique to the main S2 mylonitic schistosity (S2plane). The S-C fabric follows a preferred orientation and turns to destroy the previous foliation that was in place.

S2 mylonitic fabrics show quartz crystals have ribbon shapes of varied sizes with stretched tails and the feldspar porphyroblasts have sigmoid shape and are both surrounded by needled shaped ferromagnesian minerals.

The trends of S2 mylonitic fabrics were measured and their stereographic projection revealed $\mathrm{N} 011^{\circ} \mathrm{E}$ as the maximum trend (figure $3 \mathrm{c}, \mathrm{d}$ and e) with an average attitude of $\mathrm{N} 024^{\circ} \mathrm{E} 61^{\circ} \mathrm{ESE}$ (figure 5a).

B2 Boudins is a boudinaged aplitic dike layer enveloped by mylonitic metagranodiorite with around $60 \mathrm{~cm}$ long and $20 \mathrm{~cm}$ wide giving an average size of $30 \mathrm{~cm}$ long and $6 \mathrm{~cm}$ wide (figure $4 \mathrm{a}$ ). The boudins observed here are formed by the stretching of aplitic dike in mylonitic metagranodiorite. 
Cross-cutting relations are preserved between the dike margins and the S2 mylonitic schistosity, showing that the dike rotated clockwise relative to the mylonitic schistosity (figure $4 \mathrm{a}$ and $\mathrm{b}$ ).

Field view highlights the rheological contrasts that develop through intercalation of lithologies of variable viscosity. In this case, the aplitic dike layer has fractured in the boudins neck, whereas mylonitic metagranodiorites are locally folded to fill the gap between boudins of aplitic dike layer (figure 4 a).

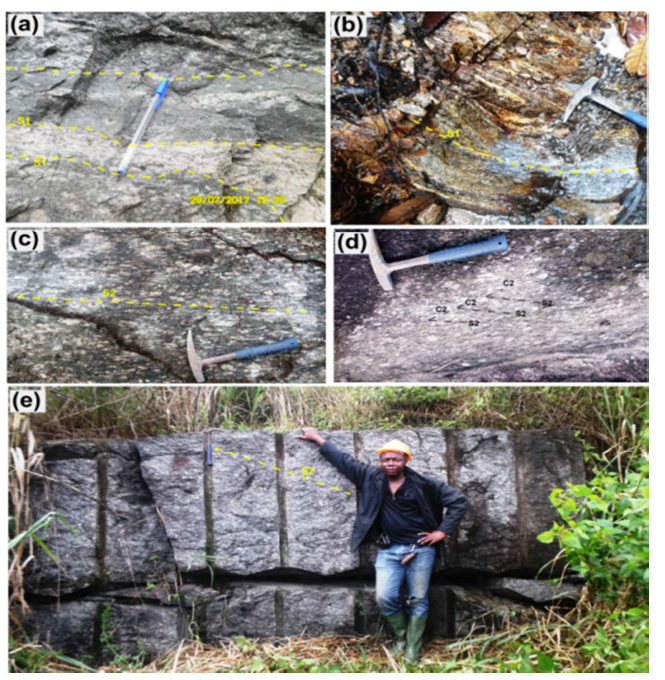

Figure 3. Fields photograhs showing (D1 to D2) deformation features: (a and b) S1 foliation in biotite gneiss basement rocks showing alternation of parallel compositional bands and lithological units; (c and e) S2 mylonitic schistosity; (d) $S$ - C Shear bands.
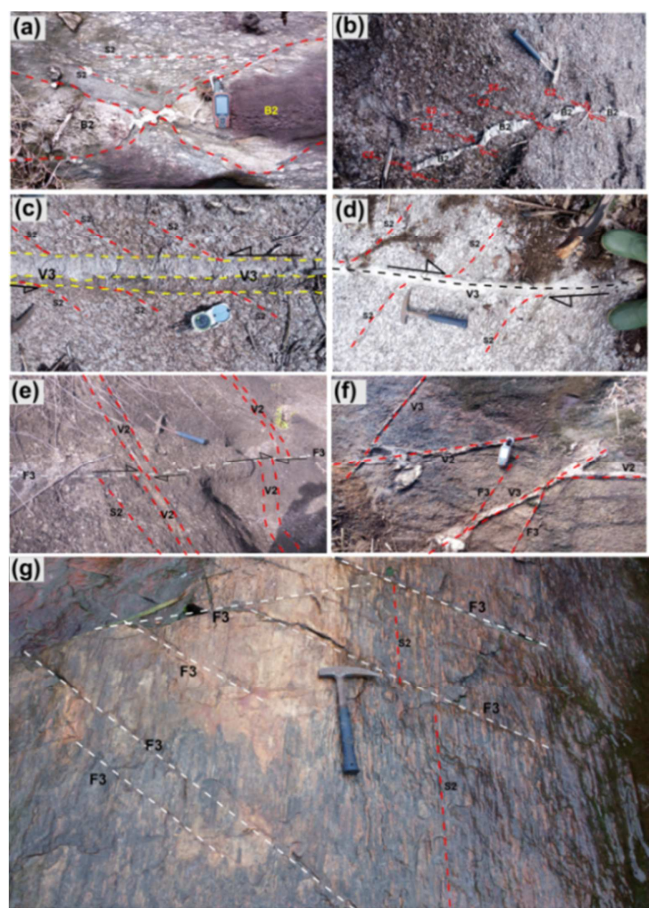

Figure 4. Field photographs showing (D2 to D3) structures in mylonitic metagranodiorite: (a) B2 boudinaged aplitic dike layer; (b) sigmoidal shaped ductile sheared asymmetric B2 boudinaged quartz vein; ( $c$ and d) V3 pegmatite to aplitic vein characterized by oblique mylonitic S2 schistosity at their margin; (e and f) F3 Faults crosscutting V2 veins and (g) F3 Faults crosscutting $S 2$ mylonitic schistosity

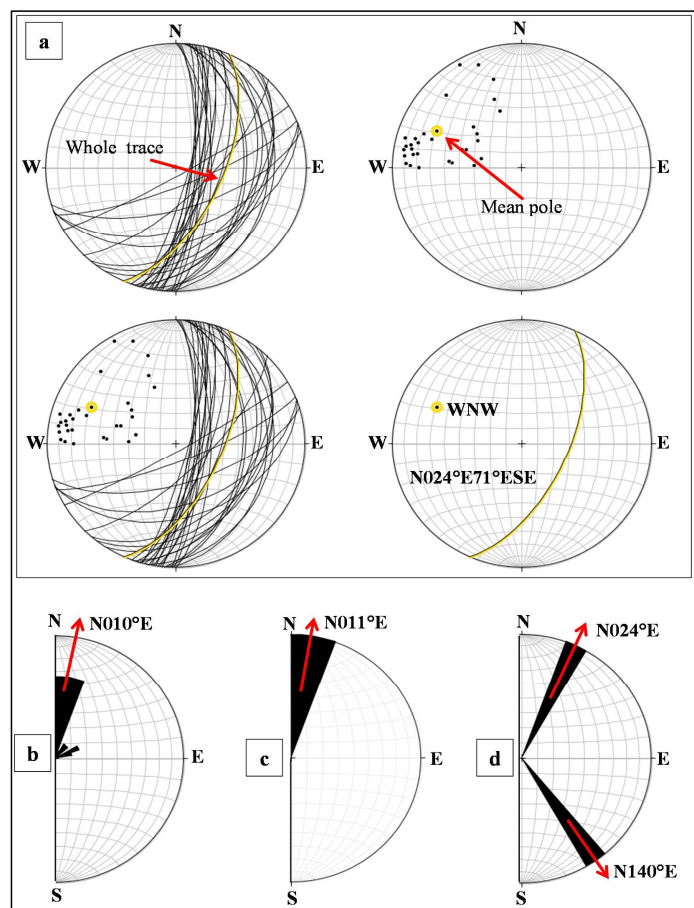

Figure 5. Stereographic representation of structures: (a) S2 cyclographic traces and poles; (b) S2 direction rose diagram; (c) B2 boudins directional rose diagram; (d) S2-C2 direction rose diagram.

\section{D3 deformation phase}

The $\mathrm{D} 3$ phase is exclusively highlighted by brittle features such as V3 veins, F3 joints and faults.

Veins

V3 Veins are joints that are filled up with late recrystallization fluids, Just like joints, they are most often grouped into two sets generally obliquely subsequent (figure $4 \mathrm{c}, \mathrm{d}, \mathrm{e}, \mathrm{f})$. As joints, the veins developed during the D3 phase exhibit an average direction of $\mathrm{N} 045^{\circ} \mathrm{E}$ and $\mathrm{N} 075^{\circ} \mathrm{E}$.

Field view also showing typical paired shear zones developed approximately symmetrically to either sides of an initial fracture (figure $4 \mathrm{c}$ and d). The fracture itself has filled to form double V3 pegmatite (c) to V3 aplitic (d) vein and fluid-rock interaction to either side of the fracture has produced a bleached zone. Similar paired shear zones develop at the boundary of relatively strong layers such as aplite dykes within the mylonitic metagranodiorite. This suggests that paired shear zones develop by reactivating boundaries of stronger layers.

Joints

F3 Joints occur as a result of tensile stress with rupture in the rock without displacement of compartments. They are developed in various directions and reveal two major sets that are obliquely sequent (Figure 6a). The two sets are striking approximately $\mathrm{N} 045^{\circ} \mathrm{E}$ and $\mathrm{N} 085^{\circ} \mathrm{E}$ (Figure 6a, c).

Faults

F3 Faults are exclusively present in the D3 phase. During this phase, faults affected the previous features of D1 and D2, following a dextral kinematics (figure $4 \mathrm{e}, \mathrm{f}, \mathrm{g}$ ). The relative displacement illustrated on Figure 4e and $f$ infers to F3 Faults a dextral shear plane characteristic. F3 Faults average strike is $140^{\circ} \mathrm{E}$. 
These fractures affect the whole area and cut across all the other structural elements indicating their late formation relatively to the other structures.
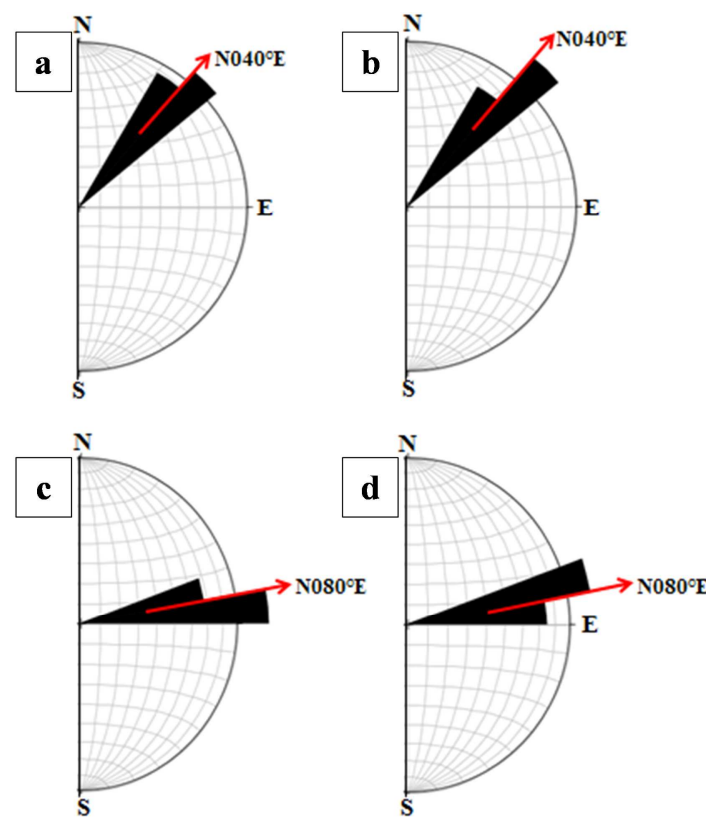

Figure 6. Stereographic projection showing the main strikes of joints (a and c) and veins (Figure b and d) for D3 deformation phase.

\section{Interpretations and Discussion}

Field campaigns in Bonguen area and Lab analysis show different aspects that took in consideration structural elements at different scales. As far as microscopic observation is concerned, mylonitic S2 features are clearly underlined by large $(\mathrm{mm}$ to $\mathrm{cm})$ crystals of feldspar exhibiting sigmoidal shapes, millimetric quartz ribbons associated with preferred orientation of biotite. Mylonitic fabrics also shown by porphyroblasts of K-feldspar is made by elongated aggregates of fine-grained biotite (dark parts) and quartz ribbons (pale gray lenticular parts) and stretched quartz porphyroclasts with elongated tails and feldspars with a sigmoid shape. Shear bands (C2-planes) develop oblique to the main S2 mylonitic schistosity (S2-plane) showing dextral ductile shear. Note the large lens-shaped orthoclase porphyroblasts ( $\sigma$-type) are surrounded by small size crystals (figure $3 \mathrm{~d}$ ). All these microstructural elements are mostly found in shear zone $[15,16]$.

The fact that mylonitic metagranodiorite are locally folded to fill the gap between boudins of aplitic dike layer that have rotated clockwise relative to the mylonitic schistosity provides an example of mixed brittle-viscous deformation at temperatures in excess of the brittle to viscous transition in aplitic rocks, and a possible geological analogue to the mixture of transient creep and episodic brittle failure (fig $4 \mathrm{a}$ and b) $[17,18]$.

Figure $4 \mathrm{~b}$ highlights sigmoidal shaped ductile sheared asymmetric boudinaged quartz vein within mylonitic metagranodiorite showing dextral shear sense associated with en-echelon shear fractures. These asymmetric boudins could correspond to boudins of «shear zone» within the limits of the extension field. In addition, based on the surface observation, V3 are sometime filled up with late recrystallization fluids, they show significant displacement having a horizontal component characterized by oblique mylonitic S2 schistosity (figure 4c and d).

All this suggests that from microscopic up to regional scale, Bonguen area have undergoing dextro-sinistral ductile shear tectonic and could thus be reported as a segment of the northern extension of the Kribi-Campo fault.

\section{Conclusion}

The results pertaining to the petrographic and the structural studies within Bonguen area reveals the following findings:

Mylonitic metagranodiorite is the major petrographic type outcroping as large domes striking almost N-S in biotite gneiss basement rocks. The rock is composed mostly of Kfs, Qtz, Bt and $\mathrm{Op}$; and it exhibits heterogranular lepidoblastic texture.

Tectonically, the area underwent ductile and brittle deformations. These events are subdivided into three major phases of deformation:

The D1 deformation phase is typically ductile and characterized by: S1 foliation in biotite gneiss basement rocks showing alternation of parallel compositional bands and lithological units.

The D2 deformation phase is more ductile and it is marked by the S2 mylonitic schistosity, the $\mathrm{C} 2$ shear, V2 veins and B2 boudins.

The D3 deformation phase is the main brittle deformation phase, underlined by brittle features such as V3 veins, F3 joints and faults.

The kinematic with 03 deformation phases displayed here, closely resembles the one described in the Fifinda-Londji (South of Bonguen) and within the Kribi-Campo shear zone, therefore the Bonguen area is likely the northern part of the KCSZ.

\section{Acknowledgements}

The authors are grateful to anonymous reviewers for their constructive comments. This paper is part of DIPES II thesis under the supervision of the first two co-authors.

\section{References}

[1] Clifford, T. N., 1970. The structural framework of Africa. $\ln$ T. N. Clifford et I. G. Gass (éds.), African magmatism and Tectonics. Olives and Boyd, Edinburgh, p. 1-26.

[2] Lerouge C., Cocherie A., Toteu S. F., Penaye J., Milesi J.-P., Tchameni R., Nsifa N. E., Fanning C. M., and Deloule E. (2006). - Shrimp U-Pb zircon age evidence for Paleoproterozoic sedimentation and $2.05 \mathrm{Ga}$ syntectonic plutonism in the Nyong Group, southwestern Cameroon: consequences for the Eburnean-Transamazonian belt of NE Brazil and Central Africa. Journal of African Earth Sciences 44, 413-427. 
[3] Lasserre, M., and Soba, D., 1976. Age libérien des granodiorites et des gneiss à pyroxènes du Cameroun méridional. Bulletin du BRGM 2, 17-32.

[4] Maurizot, P., Abessolo, A., Feybesse, J. L., Johan, V., Lecomte, P., 1986. Etude et prospection minière du Sud-Ouest Cameroun. Synthèse des travaux de 1978 à 1985. Rapport BRGM 85 CMR 066.

[5] Feybesse, J. L., Johan, V., Triboulet, C., Guerrot, C., MayagaMikolo, F., Bouchot, V., Eko N'dong, J., 1998. The West Central African belt: a model of 2.5-2.0 Ga accretion and twophase orogenic evolution. Precambrian Research 87, 161216.

[6] Maurizot, P., 2000. Geological map of south-west Cameroon. Edition BRGM, Orleans.

[7] Madaha Kodjo, V., 2016. Pretrographic and structural characterization of the KRIBI-CAMPO fault in FIFINDALONDJI area. Dissertation, DIPES II, Univ. Bda, 93p.

[8] Kankeu, B., Greiling, R. O., Nzenti, J. P., Ganno, S., Danguene, P. Y. E., Bassahak, J., Hell, J. V., 2017. Contrasting Pan-African structural styles at the NW margin of the Congo Shield in Cameroon. Journal of African Earth Sciences, http://dx.doi.org/10.1016/j.jafrearsci.2017.06.002.

[9] Nedelec, A., Nsifa, E., Martin, H., 1990. Major and trace element geochemistry of the Archaean Ntem plutonic complex (South Cameroon): petrogenesis and crustal evolution. Precambrian Research 47, 35-50. http://dx.doi.org/10.1016/0301-9268(90)90029-P.

[10] South-West Cameroon of two doleritic episodes initiating the Eburnean (Palaeoproterozoic) and Pan-African (Neoproterozoic) orogenic cycles, In: Comptes rendus de l'academie des sciences serie ii fascicule des Sciences de la Terre et des planetes 323, 575-582.

[11] Ndema Mbongue, J. L., Ngnotué, T., Ngo Nlend, C. D.,
Nzenti, J. P., and Suh, C. E., 2014. Origin and evolution of the formation of the Cameroon Nyong series in the western border of the Congo craton. Journal of Geosciences and Geomatics 2, 62-75.

[12] Ganno, S., Moudioh, C., Nzina Nchare, A., Kouankap Nono, G. D., and Nzenti, J. P., 2015. Geo-chemical fingerprint and iron ore potential of the siliceous itabirite from Palaeoproterozoic Nyong series, Zambi area, Southwestern Cameroon. Resource Geology 66, 71-80.

[13] Maurizot, P., Abessolo, A., Feybesse, J. L., Johan, V., Lecomte, P., 1985. Etude et prospection minière du Sud-Ouest Cameroun. Synthèse des travaux de 1978 à 1985. Rapport $B R G M$ 85, CMR 066, 274 p.

[14] Shang C, K., Liégeois J, P., Satir, M., Frisch, W., and Nsifa. E. N., 2010. Late Archaean high-K granite geochronology of the northern metacratonic margin of the Archaean Congo craton, Southern Cameroon: Evidence for Pb-loss due to nonmetamorphic causes. International Association for Gondwana Research 475, 19p.

[15] Njonfang, E., Moreau, C., Tchoua, F. M., (1998). La bande mylonitique Foumban-Bankim. Ouest Cameroon. Une zone de cisaillement de haute temperature. Comptes Rendus Academie des sciences, Paris, 327, PP 735-741.

[16] Njonfang Emmanuel, Ngako Vincent, Kwekam Maurice, Affaton Pascal (2006). Les orthogneiss calco-alcalins de Foumban-Bankim: témoins d'une zone interne de marge active panafricaine en cisaillement. C. R. Geoscience 338 (2006) 606-616.

[17] Fossen, H., 2016. Structural Geology, second ed. Cambridge University Press.

[18] Mukherjee, S., 2014. Atlas of Shear Zone Structures in Mesoscale, Springer Geology, p128. DOI: 10.1007/978-3-31900089-3 4 . 